\title{
Effect of Temperature Regime and Growth Stage Interaction on Pattern of Virus Presence in TSWV-Resistant Accessions of Capsicum chinense
}

\author{
Salvador Soler, M. José Díez, and Fernando Nuez, Departamento de Biotecnología, Universidad Politécnica de \\ Valencia, Valencia 46022, Spain
}

\begin{abstract}
Soler, S., Díez, M. J., and Nuez, F. 1998. Effect of temperature regime and growth stage interaction on pattern of virus presence in TSWV-resistant accessions of Capsicum chinense. Plant Dis. 82:1199-1204.

We studied the resistance to tomato spotted wilt virus in plant introduction accession (PI)151225 and PI-159236 under Mediterranean climatic conditions. Two temperature regimes were utilized, corresponding to early and late cultivation cycles. Inoculations were made at 2- and 4leaf stages to determine the effect of early infection. The existence of interaction between temperature regime and developmental stage was also studied. When plants of both PIs were maintained at $30 / 18^{\circ} \mathrm{C}$ (day/night), all plants at both growth stages when inoculated developed systemic infection. At $25 / 18^{\circ} \mathrm{C}$, only those plants inoculated at 2 -leaf stage became systematically infected; however, those inoculated at the 4-leaf stage behaved as resistant. Thus, there was an interaction between temperature regime and growth stage. There is potential for using this type of resistance in areas with mild climates, providing seedling infections are avoided.
\end{abstract}

Additional keywords: hypersensitive reaction, virus distribution

Tomato spotted wilt virus (TSWV), type member of the plant virus genus Tospovirus (Bunyaviridae), affects a large number of plant species. This virus is transmitted by several species of thrips (Thripidae: Thysanoptera; 33,36 ), and is able to produce various symptoms in infected plants. The appearance and severity of symptoms varies depending on the host, age of the plant, and environmental conditions (12). Typical symptoms in pepper plants infected with TSWV are chlorosis and necrosis of the new growth; necrotic (usually concentric) lesions on leaves, stems and fruits; and an overall plant stunting (6).

Resistance sources to TSWV have been reported in some species of Capsicum (1,7,27,35,37). C. chinense PI-152225 and PI-159236 have been reported as highly resistant to TSWV in field conditions and mechanical inoculation $(5,10,30)$. Resistance in these accessions is manifested by the appearance of hypersensitive lesions, followed by the abscission of the inocu-

Corresponding author: F. Nuez

E-mail: fnuez@btc.upv.es

This contribution was financially supported by the Instituto Nacional de Investigaciones Agrarias (SC97-105-C5-1).

Accepted for publication 7 July 1998.

Publication no. D-1998-0901-03R

This article is in the public domain and not copyrightable. It may be freely reprinted with customary crediting of the source. The American Phytopathological Society, 1998. lated leaves $(3,4,6)$. The hypersensitive response in these accessions occurs independently of the growth stage of the plant and the temperature (34), but the ability to avoid infection can be affected by other factors, such as the virus isolate (31), temperature (28), inoculum pressure, growth stage of the plant (34), and genetic background $(17,31)$.

Here, we analyze two of these factors: the temperature regime and the growth stage of the plants at the time of inoculation. A small percentage of systemically infected plants of PI-152225 and PI159236 has been observed by some authors after inoculating with TSWV. Roggero et al. (34) found a break in the resistance when mechanically inoculated plants were maintained in a continuous $33^{\circ} \mathrm{C}$ temperature regime. This implies the impossibility of growing these accessions in tropical climates with high temperatures and low thermic fluctuations without disease symptoms. The age of the plant at the time of inoculation is also an important factor affecting the stability of the resistance. Thus, Nono-Womdim et al. (26) observed that pepper accessions resistant to cucumber mosaic virus (CMV) inoculated at a growth stage younger than 4 to 5 developed leaves were susceptible.

We studied TSWV resistance in PI152225 and PI-159236 under simulated Mediterranean climatic conditions. Two temperature regimes were utilized, corresponding to early and late cultivation cycles, which are characterized by significant day/night temperature fluctuations. We also studied plant response to growth stage when infected ( 2 and 4 developed leaves) and the interaction with temperature.

\section{MATERIAL AND METHODS}

Plant material and growth conditions. Resistant accessions PI-152225 and PI159236 of $C$. chinense and the susceptible cultivar Negral of $C$. annuum were used in this work. Four groups of 105 plants (35 plants per accession) were placed in pots measuring 6 by 6 by $8 \mathrm{~cm}$. Plants were randomly distributed in polyethylene trays. Two groups were maintained in a growth chamber with an 11 -h light cycle: $25^{\circ} \mathrm{C}$ and 60 to $65 \%$ relative humidity (RH) day, $18^{\circ} \mathrm{C}$ and 95 to $100 \% \mathrm{RH}$ night. The other two groups were kept in another climatic chamber with the same light cycle and $\mathrm{RH}$, but the temperature was $30 / 18^{\circ} \mathrm{C}$ day/ night. Grolux fluorescent tubes (Sylvania) providing 65 to $85 \mu \mathrm{mol}$ photons $\mathrm{m}^{-2} \mathrm{~s}^{-1}$ (at a wavelength between 400 and $700 \mathrm{~nm}$ ) were used.

Inoculum and inoculation. Isolate HA931100 of TSWV was collected from thrips feeding on TSWV-infected broad bean and artichoke plants in two adjacent fields in Campo de Cartagena (Murcia, Spain). Thrips were collected and fed on healthy plants of Negral. This inoculum was maintained on susceptible plants of tomato line NE-1 and on pepper cultivar Negral, grown in cages covered with antithrips mesh, in a climatic chamber. Environmental conditions were $22^{\circ} \mathrm{C}, 45$ to $55 \% \mathrm{RH}$, day; and $25^{\circ} \mathrm{C}, 85$ to $100 \% \mathrm{RH}$, night. A photoperiod of $14 \mathrm{~h}$ light was provided by Grolux fluorescent tubes (Sylvania) with an irradiance of $120 \mu \mathrm{mol}$ photons $\mathrm{m}^{-2} \mathrm{~s}^{-1}$. Plants were periodically replaced to ensure food supply for the thrips. Virus transmission was carried out by thrips to avoid the appearance of defective forms (14).

Inoculum was prepared by grinding infected leaves of tomato line NE-1 in cold $0.1 \mathrm{M}$ phosphate buffer, $\mathrm{pH}$ 7.0, containing $0.2 \% \mathrm{Na}_{2} \mathrm{~S}_{2} \mathrm{O}_{5}$ and $0.2 \%$ sodium diethyldithiocarbamate in a proportion of $1: 5$ (wt/vol) and 1\% 600 mesh Carborundum. Two groups of plants (second expanded leaf stage) kept in each of the growth conditions were inoculated on the second leaf. The other two groups of plants (fourth expanded leaf stage) were inoculated on the fourth leaf. Inoculated leaves were divided into two similar areas transversally to the midrib (apical and basal areas). A cotton-tipped applicator was dipped in 
inoculum and rubbed on the apical area of the leaves.

Pattern of virus presence. Samples from the apical, basal areas and petiole of the inoculated leaf, and from the apex and root of the plant, were tested for the presence of the virus. Samples from seven plants per accession and treatment were taken at $3,7,12,18$, and 25 days postinoculation (DPI). Detection of the virus was performed by double-antibody sandwich-enzyme-linked immunosorbent assay (DAS-ELISA) technique. The absorbance was measured by a Titertek Multiskan MCC/340 photometer (405 nm). Samples were considered positive when their absorbance values exceeded three times that of the healthy mean.

The number of days necessary to detect the virus in one particular organ in at least $25 \%$ of the inoculated plants has been calculated in order to facilitate data interpretation. We have called this period Post
Inoculation Period-25 (PIP-25). A pattern of virus presence was defined by the corresponding PIP-25 values in each analyzed tissue.

\section{RESULTS}

Effect of temperature on the pattern of virus presence. Plants of the susceptible cultivar Negral inoculated on the second leaf showed $100 \%$ infection in the inoculated area 3 days after inoculation. When plants were maintained at $25 / 18^{\circ} \mathrm{C}$, viral infection was detected in each analyzed area of the plant 7 days after inoculation. Once the virus reached the petiole, the invasion of the whole plant was rapid. The same behavior was observed at $30 / 18^{\circ} \mathrm{C}$. Virus movement in Negral was equally rapid at both temperature regimes as revealed by the values of the PIP-25 (Table 1).

Virus movement was delayed in resistant accessions. When plants of PI-159236

Table 1. Number of days necessary to detect the virus in various tissues in at least $25 \%$ of the inoculated plants $(\mathrm{PIP}-25)^{\mathrm{x}}$

\begin{tabular}{|c|c|c|c|c|c|}
\hline \multirow[b]{2}{*}{ Regime $^{\mathrm{y}}$} & \multirow[b]{2}{*}{ Growth stage } & \multirow[b]{2}{*}{ Tissue } & \multicolumn{3}{|c|}{ PIP-25 } \\
\hline & & & PI-159236 $^{\mathrm{Z}}$ & PI-152225 & Negral \\
\hline \multirow[t]{10}{*}{$25 / 18^{\circ} \mathrm{C}$} & \multirow[t]{5}{*}{ Second leaf } & Inoculated area & 1 & 1 & 0.75 \\
\hline & & Leaf base & 8 & 11 & 3.5 \\
\hline & & Petiole & 14.5 & 14 & 3.5 \\
\hline & & Plant root & 20 & 17 & 3.5 \\
\hline & & Plant apex & 14 & 17 & 3.5 \\
\hline & \multirow[t]{5}{*}{ Fourth leaf } & Inoculated area & 1 & 1 & 0.75 \\
\hline & & Leaf base & 12 & 19 & 3.5 \\
\hline & & Petiole & $>25$ & $>25$ & 3.5 \\
\hline & & Plant root & $>25$ & $>25$ & 3.5 \\
\hline & & Plant apex & $>25$ & $>25$ & 3.5 \\
\hline \multirow[t]{10}{*}{$30 / 18^{\circ} \mathrm{C}$} & \multirow[t]{5}{*}{ Second leaf } & Inoculated area & 1 & 1 & 0.75 \\
\hline & & Leaf base & 8 & 14 & 3.5 \\
\hline & & Petiole & 12 & 16.5 & 3.5 \\
\hline & & Plant root & 16.5 & 16.5 & 3.5 \\
\hline & & Plant apex & 12 & 16.5 & 3.5 \\
\hline & \multirow[t]{5}{*}{ Fourth leaf } & Inoculated area & 1 & 1 & 0.75 \\
\hline & & Leaf base & 17 & 20 & 3.5 \\
\hline & & Petiole & 17 & 20 & 3.5 \\
\hline & & Plant root & 17 & 23.5 & 3.5 \\
\hline & & Plant apex & 17 & 23.5 & 4 \\
\hline
\end{tabular}

${ }^{x}$ PIP-25 = post-inoculation period-25.

y Day/night temperatures.

${ }^{\mathrm{z}} \mathrm{PI}=$ plant introduction accession, and $\mathrm{cv}$. Negral of Capsicum chinense .

Table 2. Symptoms of plants infected with tomato spotted wilt virus 7 to 25 days after inoculation ${ }^{\mathrm{w}}$

\begin{tabular}{lrrrrr}
\hline & & \multicolumn{3}{c}{ Symptoms } \\
\cline { 5 - 6 } Regime $^{\mathbf{x}}$ & Inoculation stage & Accession & 12 DPI & 18 DPI & \multicolumn{1}{c}{ 25 DPI } \\
\hline $25 / 18^{\circ} \mathrm{C}$ & Second leaf & Negral & D2, N1 & D3,SR1,N2 & D3,SR3,N3 \\
& Fourth leaf & Negral & D2 & D3,SR1,N1 & D3,SR3,N3 \\
$30 / 18^{\circ} \mathrm{C}$ & Second leaf & PI-159236 & D2,A2 & D3,A3 & D3,SR2,A3,N2 \\
& & PI-152225 & D2,A2 & D2,A2 & D3,SR2,A3,N2 \\
& & Negral & D2,SR2,N2 & D3,SR3,N2 & D3,SR3,N3 \\
& \multirow{2}{*}{ Fourth leaf } & PI-159236 & $\ldots$ & D2 & D3,SR2,A2,N1 \\
& & PI-152225 & $\ldots$ & $\ldots$ & D3,SR2,A3 \\
& & Negral & D2,R2 & D3,SR3,N1 & D3,SR3,N3 \\
\hline
\end{tabular}

${ }^{\mathrm{w}}$ At the $25 / 18^{\circ} \mathrm{C}$ regime, plant introduction accession (PI)-152225 and PI-159236 plants of Capsicum chinense inoculated at the 4-leaf stage remained symptomless. C. chinense cv. Negral plants displayed limited leaf distortion and ringspots after 7 days.

$\mathrm{x}$ Day/night temperatures.

${ }^{\mathrm{y}} \mathrm{DPI}=$ days post-inoculation.

${ }^{\mathrm{z}} \mathrm{D}=$ distorted leaves, $\mathrm{N}=$ stem necrosis, $\mathrm{SR}=$ chlorotic spots/rings, $\mathrm{A}=$ distorted apex; 1 = low severity, $2=$ medium severity, and $3=$ high severity; $\ldots=$ no symptoms. inoculated at the second leaf were maintained at $25 / 18^{\circ} \mathrm{C}$, systemic infection was observed in almost $50 \%$ of the plants (data not shown). A delayed migration of the virus to the basal area of the inoculated leaf was detected 25 DPI (PIP $=8$ in comparison to 3.5 in Negral; Table 1). This delay increased compared with the values of PIP-25 in the petiole of the inoculated leaf, root, and plant apex. When plants were kept at a $30 / 18^{\circ} \mathrm{C}$ day/night temperature regime, virus movement in PI159236 was faster throughout the plants (Table 1). The same phenomenon was observed with accession PI-152225, but systemic movement at $30 / 18^{\circ} \mathrm{C}$ was not as fast as in accession PI-159236.

Effect of the vegetative growth on the pattern of virus presence. There was no effect of the stage of vegetative growth of the inoculated plants on the pattern of virus presence in cv. Negral. Even when plants were inoculated at the more advanced growth stage, the infection on every area of the plant was observed 7 DPI (data not shown). The values of PIP-25 were similar for the two growth stages (Table 1).

When the assay was performed at $25 / 18^{\circ} \mathrm{C}$, the response of the two resistant accessions was dependent on the growth stage of the inoculated plants. About half of the plants inoculated at the 2-leaf stage became systemically infected, while the presence of the virus was limited to the inoculated leaves when plants were inoculated at the 4-leaf stage. Thus, the values of the PIP-25 were higher than 25 days in the petiole, root, and apex plant tissues (Table 1). A delay of virus movement to the basal area of the inoculated leaves was also detected on plants inoculated on the fourth leaf (PIP-25 = 12) in comparison to plants inoculated on the second leaf (PIP-25 $=8$ ) in PI-159236. This delay was higher in PI152225 accession, with a value of PIP-25 = 19.

Interactive effects between the temperature regime and the growth stage on the pattern of virus presence. Plants of PI-159236 inoculated in the 4-leaf stage and grown at $25 / 18^{\circ} \mathrm{C}$ did not become systemically infected within 25 DPI (Table 1). Those grown at $30 / 18^{\circ} \mathrm{C}$ were systemically infected regardless of growth stage when inoculated. The same response was observed in PI-152225, although virus migration was slower, especially to the roots and apices.

Relationship between virus accumulation values and symtomatology. The susceptible cultivar Negral showed severe systemic symptoms in all the experiments. At the higher temperature regime, symptoms appeared earlier, and were more severe, than at the lower regime. Symptoms were also increased by temperature in the resistant accessions. When inoculations were performed at $25 / 18^{\circ} \mathrm{C}$, no plants showed systemic symptoms, but when inoculated at $30 / 18^{\circ} \mathrm{C}$ (Table 2), all in- 
fected plants developed systemic symptoms. As a rule, systemic symptoms in resistant accessions were less severe and delayed compared with those observed in cv. Negral, although the severity of systemic symptoms were similar in both the susceptible cultivar and the resistant accessions at the end of the experiment. Systemic symptoms in the susceptible cultivar Negral were not affected by the developmental stage in which the plants were inoculated. In trials carried out at $30^{\circ} \mathrm{C}$, systemic symptoms appeared 5 days later when plants were inoculated on the fourth leaf (Table 2).

Hypersensitive lesions appeared only in the inoculated area, although virus was also detected in the basal area of inoculated leaves. The moment of appearance of hypersensitive lesions in the inoculated leaf was independent of the temperature for both PI-152225 and PI-159236 (Table 3). Nevertheless, in both accessions, their number was increased when plants were inoculated at $30 / 18^{\circ} \mathrm{C}$. In this temperature regime, the growth stage of the plant had an important effect on the appearance of hypersensitive reactions. Necrotic lesions were more abundant in plants inoculated on the fourth leaf.

Values of absorbance. The tests on inoculated area were positive 3 days after inoculation in cv. Negral. Virus was detected 7 days after inoculation in every tissue analyzed: basal area, petiole of the inoculated leaf and root, and apex of the plant. This response was independent of the growth stage and the temperature regime. However, an increase in the temperature led to an increase of the absorbance values in the inoculated area on the first dates of sampling, and a decrease at the end of the trial. In all cases, an increase of the values was observed reaching a maximum 12 days after inoculation. Values decreased slowly after this date (Fig. 1).

Absorbance values were always lower in the resistant accessions than those of $\mathrm{cv}$.
Negral. As in the susceptible cultivar Negral, positive values were obtained 3 days after inoculation in the inoculated area. However, the increase of values in the different tissues of the plant was delayed and dependent on both the temperature and the growth stage of the plant at inoculation. In most cases, the virus did not reach the apex of the plant until 12 DPI. An increase in the temperature combined with inoculation at an early growth stage led to an increase in the absorbance values. Growth stage was especially important in the experiments conducted at $25 / 18^{\circ} \mathrm{C}$, in which plants inoculated on the fourth leaf showed a blocking of the virus migration in the petiole, giving negative values of absorbance in the petiole, root, and apex of the plant. Plants of PI-152225 gave lower values of absorbance in the apex of the plant than plants of PI-159236. This difference was greater in plants inoculated on the fourth leaf. This tendency was also noted in the basal area and petiole of the inoculated leaf and in the root (data not shown).

Evolution of absorbance values was different than those observed in cv. Negral. A slow and constant increase of the values occurred in trials conducted at a $25 / 18^{\circ} \mathrm{C}$ regime. In experiments carried out at $30^{\circ} \mathrm{C}$, the increase was more rapid and in some cases decreased at the end of the experiment (Fig. 1). In trials developed at this temperature regime, absorbance values matched those in the final sampling data.

\section{DISCUSSION}

Accessions of C. chinense, PI-152225 and PI-159236, are resistant to TSWV if infected at a growth stage not earlier than four developed leaves, and if plants are maintained at a temperature regime with a maximum of $25^{\circ} \mathrm{C}$. Reports indicate that plants develop a hypersensitive response (HR) without systemic infection $(11,20)$. Nevertheless, the HR is not complete because these lesions are unable to localize the virus at the point of infection. Virus can be detected in the inoculated and basal area of the leaf, although at levels much lower than in the susceptible cultivar Negral. This suggests the existence of a restriction mechanism which prevents the movement of the virus in tissues of resistant plants $(22,32)$, a reduction of viral multiplication $(18,19,38,39)$, or a restriction of cell-tocell movement $(8,23,24)$. The two mechanisms lead to a decrease in virus accumulation and to a delay in spread of the virus through the plant tissues $(16,26)$. Analysis of evolution of the infection in the inoculated area of the resistant accessions have shown the virus to be localized in small areas that slowly increase (data not shown). The lower absorbance values could be caused by a smaller area of infected tissue and not to a lower viral replication. This suggests that a restriction of cell-to-cell movement could operate in PI152225 and PI-159236, retarding the spread of the virus to the inoculated and basal areas of the leaf. The mechanism could be operating on a mesophil level, probably interfering with the transport function of the NSm protein (15), preventing virus from reaching the vascular system (22). Sequential analysis of the NSm movement protein as well as experiments with protoplasts would verify the suggested hypothesis. Elucidation of the underlying resistance mechanism is of great interest for breeders seeking to accumulate different resistance mechanisms in order to develop varieties with durable resistance.

Growing plants at high temperatures $\left(30 / 18^{\circ} \mathrm{C}\right.$ day/night regime) leads to the modification of the pattern of virus presence in the plant tissues, resulting in the systemic infection of the plants. Resistance break due to high temperatures has been reported with other viruses. For example, an increase in the temperature from 25 to $32^{\circ} \mathrm{C}$ leads to a breaking of resistance, characterized by a block in the virus movement through the petiole of the

Table 3. Mean number of local lesions in the inoculated areas of the resistant accessions on each sampling date indicated

\begin{tabular}{|c|c|c|c|c|c|c|c|}
\hline \multirow[b]{2}{*}{ Regime $^{w}$} & \multirow[b]{2}{*}{ Growth stage } & \multirow[b]{2}{*}{ Accession $^{\mathrm{x}}$} & \multicolumn{5}{|c|}{ Mean number of lesions ${ }^{v}$} \\
\hline & & & 3 DPI $^{\mathbf{y}}$ & 7 DPI & 12 DPI & 18 DPI & 25 DPI \\
\hline \multirow[t]{6}{*}{$25^{\circ} \mathrm{C} / 18^{\circ} \mathrm{C}$} & Second leaf & PI-159236 & 0 & 0.86 & 0.57 & 1 & 1.14 \\
\hline & & PI-152225 & 0 & 0.43 & 0.72 & 1 & 0.57 \\
\hline & & Negral & $\ldots^{\mathrm{z}}$ & & & & \\
\hline & Fourth leaf & PI-159236 & 0.86 & 0.86 & 1 & 1 & 0.57 \\
\hline & & PI-152225 & 0 & 1.57 & 1.14 & 1.14 & 0.71 \\
\hline & & Negral & & & & & \\
\hline \multirow[t]{6}{*}{$30^{\circ} \mathrm{C} / 18^{\circ} \mathrm{C}$} & Second leaf & PI-159236 & 0 & 1.14 & 1.14 & 1.14 & 1 \\
\hline & & PI-152225 & 0.29 & 1.57 & 2 & 1.72 & 2.85 \\
\hline & & Negral & & & & & \\
\hline & Fourth leaf & PI-159236 & 0 & 3.85 & 5.42 & 4.86 & 4.71 \\
\hline & & PI-152225 & 0.57 & 3.43 & 6.43 & 4.14 & 4.28 \\
\hline & & Negral & $\ldots$ & $\ldots$ & $\ldots$ & $\ldots$ & $\ldots$ \\
\hline
\end{tabular}

\footnotetext{
${ }^{\mathrm{v}}$ Seven plants were tested at each sampling date.

${ }^{\mathrm{w}}$ Day/night temperature.

${ }^{x} \mathrm{PI}=$ plant introduction accession, and $\mathrm{cv}$. Negral of Capsicum chinense .

$\mathrm{y}$ DPI $=$ days post-inoculation.

${ }^{\mathrm{z}} \ldots=$ no symptoms.
} 
Inoculated area, second leaf, $25^{\circ} \mathrm{C} / 18^{\circ} \mathrm{C}$.

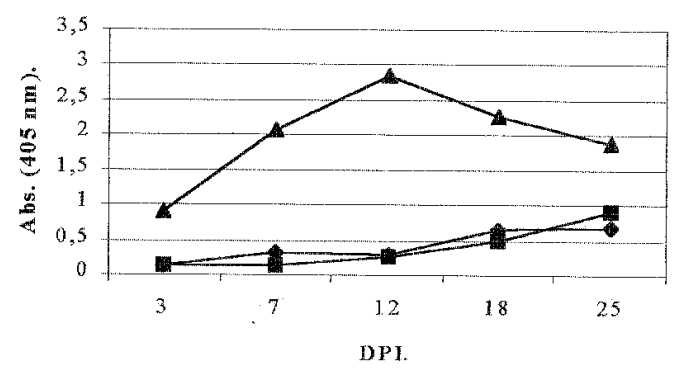

Plant apex, second leaf, $25^{\circ} \mathrm{C} / 18^{\circ} \mathrm{C}$.

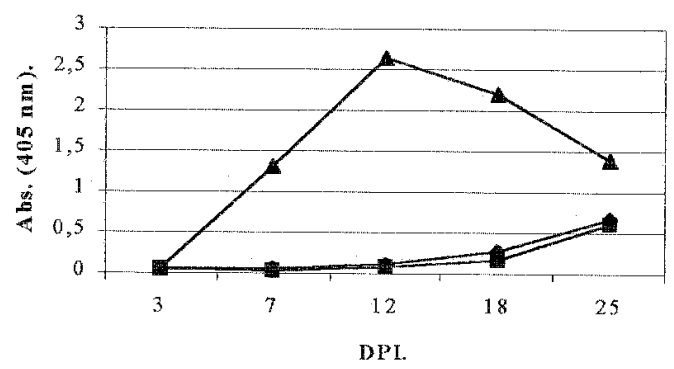

Inoculated area, second leaf, $30^{\circ} \mathrm{C} / 18^{\circ} \mathrm{C}$.

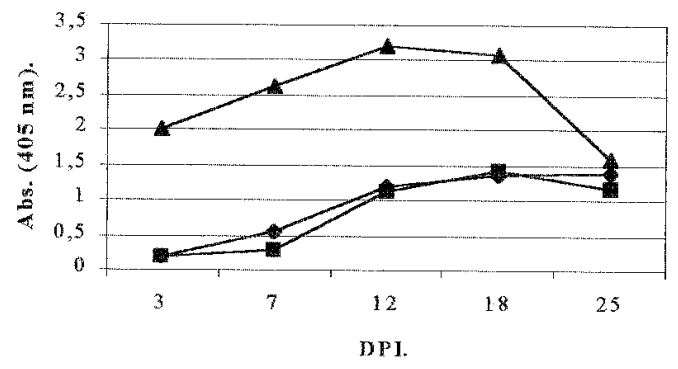

Plant apex, second leaf, $30^{\circ} \mathrm{C} / 18^{\circ} \mathrm{C}$.

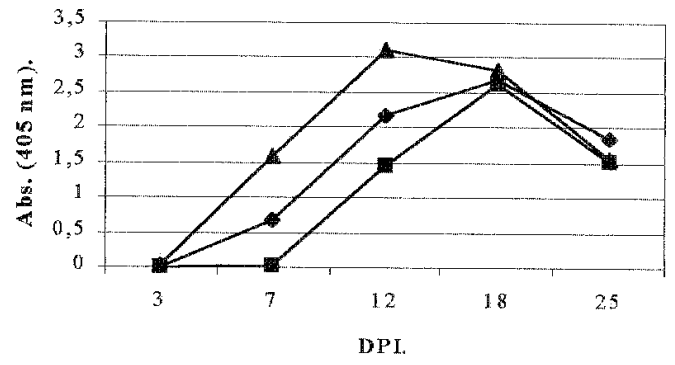

Inoculated area, fourth leat, $25^{\circ} \mathrm{C} / 18^{\circ} \mathrm{C}$.

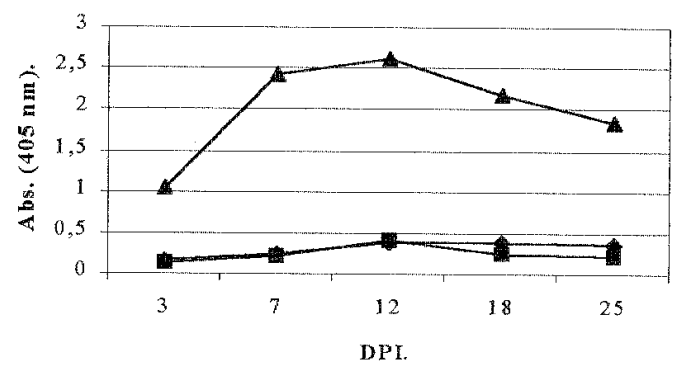

Plant apex, fourth leaf, $25^{\circ} \mathrm{C} / 18^{\circ} \mathrm{C}$.

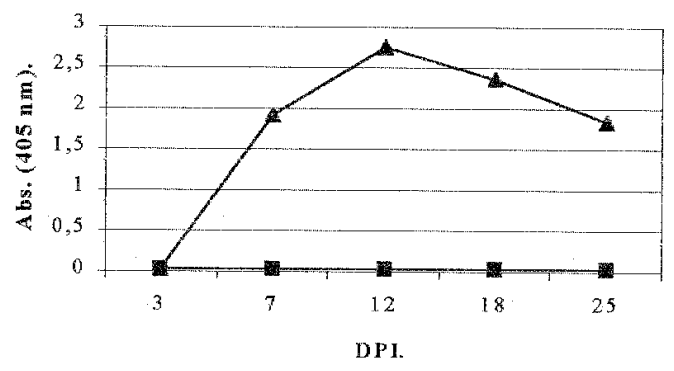

Thoculated area, fourth leaf, $30^{\circ} \mathrm{C} / 18^{\circ} \mathrm{C}$.

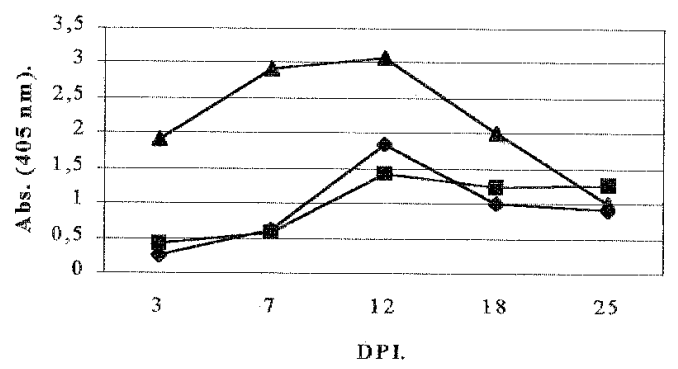

Plant apex, fourth leaf, $30^{\circ} \mathrm{C} / 18^{\circ} \mathrm{C}$.
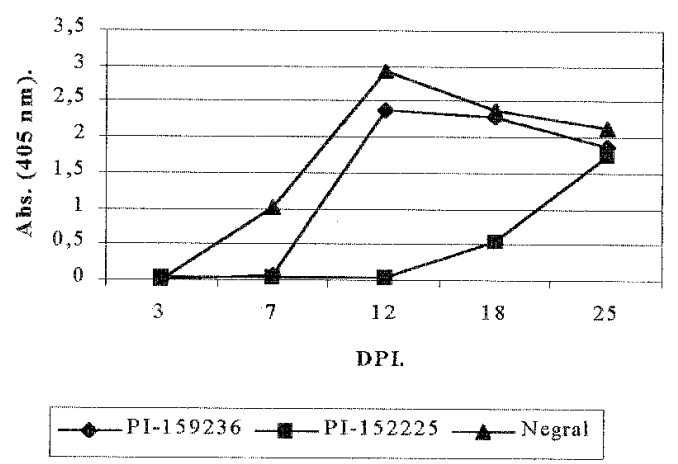

Fig. 1. Evolution of enzyme-linked immunosorbent assay absorbance values in inoculated leaves and plant apex of pepper plants. 
inoculated leaf in lines of pepper resistant to CMV (26). Modification of virus distribution also has been observed in wheat plants resistant to soilborne wheat mosaic virus (SBWMV) as the temperature increases (25). High temperature affects the tridimensional structure of the coat protein, which acts as elicitor of the HR in the tobacco mosaic virus (TMV; 13). The possibility that an increase in the temperature prevents the accumulation of salicylic acid in resistant genotypes has been reported (42). Salicylic acid acts as an inductor of different biochemical reactions in the HR (21). Accumulation of the virus in plant tissues is greater than at lower temperatures, as shown by absorbance values in ELISA assays, and correlates with the development (9) of systemic symptoms of similar severity to those induced in cv. Negral. Higher viral accumulation could allow the virus to reach the phloem when the leaf is acting as a photosynthate exporter. However, plants of accessions PI-152225 and PI-159236 infected at $25 / 18^{\circ} \mathrm{C}$ (2-leaf stage) did not develop systemic symptoms even when the virus was systemic. An increase in the temperature caused a speeding up of the disease in susceptible plants, with senescence of the infected tissue occurring earlier (41). Thus, the decrease of the absorbance values in the final sampling data could be due to virus degeneration in senescent tissues. Absorbance values of resistant accession in the inoculated area matched those of cv. Negral at the end of the experiment because of the slower development of the disease in $C$. chinense plants.

The inoculation of plants at an earlier growth stage leads to the appearance of systemic infection. This response could be due to resistance mechanisms that are not totally developed in young plants $(2,40)$. Infection is prevented only when plants are inoculated at the fourth developed leaf stage. In experiments carried out at $30 / 18^{\circ} \mathrm{C}$, plants inoculated at both 2 - and 4-leaf stages became systemically infected. However, the response is not the same. A slight delay in the systemic movement of the virus occurs when plants are inoculated at the latest growth stage. This suggests that infection in very early growth stages has a stronger effect than when infection is produced as a consequence of the break in the resistance due to an increase in temperature. These results do not agree with those of Roggero et al. (34). Inoculations of plants at the 4-leaf stage carried out by these authors under a temperature regime of $30 / 20^{\circ} \mathrm{C}$ lead to a resistant response. The different inoculum concentration (1:5 $\mathrm{wt} / \mathrm{vol}$ versus $1: 100 \mathrm{wt} / \mathrm{vol}$ ) could be the cause of the different results (34).

The dependence on the temperature regime of this resistance restricts its utilization in areas in which pepper cultivation occurs at day/night temperatures higher than $30 / 18^{\circ} \mathrm{C}$. This implies a difficult problem, because pepper is a thermophilic crop cultivated in tropical and temperate climates in the summer season. However, if seedling infection is prevented, cultivation of genotypes with resistance from PI152225 and PI-159236 could be carried out in climates in which temperatures are within the $25 / 18^{\circ} \mathrm{C}$ range. These climatic conditions usually occur in early and late cultivation cycles in the Mediterranean area (29).

\section{ACKNOWLEDGMENTS}

We thank F. García-Arenal and F. Ponz for useful discussion of manuscript; and the Conselleria de Cultura, Educació i Ciència de la Generalitat Valenciana for S. Soler's predoctoral research grant.

\section{LITERATURE CITED}

1. Beemster, A. B. R. 1958. Transport van Xvirus in de Aardappel (Solanum tuberosum L.) Bij primaire infectie. Tjdschrift PflanZiekten 64:165-262.

2. Black, L. L., Hobbs, H. A., and Gatti, J. M., Jr. 1991. Tomato spotted wilt virus resistance in Capsicum chinense PI-152225 and PI159236. Plant Dis. 75:853.

3. Boiteaux, L. S. 1995. Allelic relationships between genes for resistance to tomato spotted wilt tospovirus in Capsicum chinense. Theor. Appl. Genet. 90:146-149.

4. Boiteaux, L. S., Cupertino, F. P., and Reifschneider, F. J. B. 1993. Capsicum chinense PI-159236: source of resistance to tomato spotted wilt virus and Phytophthora capsici. Capsicum Eggplant Newl. 12:76.

5. Boiteaux, L. S., and de Ávila, A. C. 1994. Inheritance of a resistance specific to tomato spotted wilt tospovirus in Capsicum chinense 'PI-159236.' Euphytica 75:139-142.

6. Boiteaux, L. S., Nagata, T., Dutra, W. P., and Fonseca, M. E. N. 1993. Sources of resistance to tomato spotted wilt virus (TSWV) in cultivated and wild species of Capsicum. Euphytica 67:89-94.

7. Cupertino, F. P., Reifschneider, F. J. B., and Batista, M. F. 1988. Avaliçao de populaçoes de Capsicum a os virus Y de batata e viracabeça do tomateiro. Fitopatol. Bras. 13:148.

8. Deom, C. M., Wolf, S., Holt, C. A., Lucas, W. J., and Beachy, R. N. 1991. Altered function of the tobacco mosaic virus movement protein in a hypersensitive host. Virology 180:251256.

9. Desvignes, J. C., Cardin, L., Pitrat, M., and Lecoq, H. 1984. Dosage immunoenzymatique (ELISA) du virus de la mosaïque du concombre. II. Multiplication comparée du virus dans les melons sensibles et résistants. Agronomie 4:137-145.

10. Díez, M. J., Nuez, F., Jordá, C., Juarez, M., and Ortega, A. 1993. Búsqueda de fuentes de resistencia al virus del bronceado (Tomato spotted wilt virus) para la mejora del tomate y pimiento. Acta. Hortic. 10:1286-1291.

11. Dufour, O., Palloix, A., Gebre Selassie, K., Pochard, E., and Marchoux, G. 1989. The distribution of cucumber mosaic virus in resistant and susceptible plants of pepper. Can. J. Bot. 67:655-660

12. Francki, R. I. B., and Hatta, T. 1981. Tomato spotted wilt virus. Pages 491-512 in: Handbook of Plant Virus Infections and Comparative Diagnosis. Kurstak, ed. Elsevier/NorthHolland Biomedical Press, Amsterdam.

13. Fraser, R. S. S. 1986. Genes for resistance to plant viruses. Critical Rev. Plant Sci. 3:257294.

14. Inoue-Nagata, A. K., Kormelink, R., Nagata,
T., Kitijia, E. W., Goldbach, R., and Peters, D. 1997. Effects of temperature and host on the generation of Tomato spotted wilt virus defective interfering RNAs. Phytopathology 87:1168-1173.

15. Kormelink, R., Storms, M., van Lent, J., Peters, D., and Goldbach, R. 1994. Expression and subcellular localization of the Nsm protein of tomato spotted wilt virus (TSWV), a putative viral movement protein. Virology 200:56-65.

16. Kuhn, C. W., Wyatt, S. D., and Brantley, B. B. 1981. Genetic control of symptoms, movement and virus accumulation in cowpea plants infected with cowpea chlorotic mottle virus. Phytopathology 71:1310-1315.

17. Laterrot, H. 1973. Resistance de la tomate au virus de la mosaïque du tabac. Difficultés rencontrées pour la sélection de variétés résistantes. Ann. Amélior. Plantes 23:287316.

18. Loebenstein, G., and Gera, A. 1981. Inhibitor of virus replication released from tobacco mosaic virus-infected protoplasts of a local lesion-responding tobacco cultivar. Virology 114:132-139

19. Loebenstein, G., and Gera, A. 1988. Resistance response of plants to virus infection. Acta Hortic. 234:403-409.

20. Makkouk, K. M., and Kumari, S. G. 1993. Movement of Bean Yellow Mosaic Virus in Susceptible and Resistant Faba Bean Genotypes. Fabis Newsl. 32:35-37.

21. Malamy, J., Henning, J., and Klessing, D. F. 1992. Temperature-dependent induction of salicyllic acid and its conjugates during the resistance response to tobacco mosaic virus infection. Plant Cell 4:359-366.

22. Melcher, U., Brannan, C. M., Gardner, C. O., and Essenberg, R. C. 1992. Diverse mechanisms resistance to cauliflower mosaic virus revealed by leaf skeleton hybridization. Arch Virol. 123:379-387.

23. Meshi, T., Motoyoshi, F., Maeda, T., Yoshiwoka, S., Watanabe, H., and Okada, Y, 1989 Mutations in the Tobacco mosaic virus 30-KD protein gene overcome TM-2 resistance in tomato. Plant Cell 1:515-522.

24. Moser, O., Gagey, M. J., Godefroy.Colburn, T., Stussi-Garaud, C., Ellwart-Tschürtz, M., Nitschko, H., and Mundry, K. W. 1988. The fate of the transport protein of tobacco mosaic virus in systemic and hypersensitive tobacco hosts. J. Gen. Virol. 69:1367-1373.

25. Myers, L. D., Sherwood, J. L., Siegerist, W. C., and Hunger, R. M. 1993. Temperature-influenced virus movement in expression of resistance to soilborne wheat mosaic virus in hard red winter wheat (Triticum aestivum) Phytopathology 83:548-551.

26. Nono-Womdim, R., Marchoux, G., Pochard, E., Palloix, A., and Gebre-Selassie, K. 1991. Resistance of pepper lines to the movement of cucumber mosaic virus. J. Phytopathol. 132:21-32.

27. Nono-Womdim, R., Palloix, A., Gebre-Selassie, K., Phally, T., Gognalons, P., and Marchoux, G. 1994. Sources of resistance to tomato spotted wilt virus in Capsicum species. Pages 237-239 in: Proc. 9th Congr. Mediterr. Phytopathol. Union, Kusadasi-Aydin, Turkey.

28. Nuez, F., Díez, M. J., Roselló, S., Lacasa, A., Jordá, C., Martín, M., and Costa, J. 1994. Genetic resistance to TSWV (Tomato spotted wilt virus) in Capsicum spp. Capsicum Eggplant Newsl. 13:86-87.

29. Nuez, F., Gil, R., and Costa, J. 1996. El cultivo de pimientos chiles y ajies. MundiPrensa, Madrid.

30. Palloix, A., Daubeze, A. M., Lefebvre, V., and Chaine, C. 1993. Researches sur le piment. Rapport d'activite 1991-92, INRA 
(Montfavet):41-52

31. Pelham, J. 1972. Strain-genotype interaction of tobacco mosaic virus in tomato. Ann. Appl. Biol. 71:219-228.

32. Pennazio, S. 1995. The hypersensitive reaction of higher plants to viruses: a molecular approach. Microbiologica 18:229-240.

33. Resende, R. De O. 1993. Generation and characterization of mutants of tomato spotted wilt virus. Ph.D. diss. Wageningen Agricultural University, Wageningen, The Netherlands.

34. Roggero, P., Lisa, V., Nervo, G., and Pennazio, S. 1996. Continuous high temperature can break the hypersensitivity of Capsicum chinense 'PI-152225' to tomato spotted wilt tospovirus (TSWV). Phytopathol. Mediterr. 35:117-120.
35. Roselló, S., Díez, M. J., Jordá, C., and Nuez, F. 1996. Screening of Capsicum chacoense accesions for TSWV resistance by mechanical inoculation. Capsicum Eggplant Newsl. 15:58-60.

36. Roselló, S., Díez, M. J., Jordá, C., and Nuez, F. 1997. Utilization of Capsicum sp. resistance to TSWV in pepper breeding. Capsicum Eggplant Newsl. 16:87-90.

37. Roselló, S., Díez, M. J., and Nuez, F. 1996. Viral diseases causing the greatest economic losses to the tomato crop. I. The Tomato spotted wilt virus (TSWV)-A review. Sci. Hortic. 67:117-1.

38. Sela, I. 1981. Plant-virus interactions related to resistance and localization of viral infections. Adv. Virus Res. 26:201-237.

39. Sela, I., Grafi, G., Sher, N., Edelbaum, O.,
Yagev, H., and Gerassi, E. 1987. Resistance systems related to the $\mathrm{N}$ gene and their comparison with interferon. Pages 92-108 in Plant Resistance to Viruses. D. Evered and S. Harnett, eds. Wiley, Chichester, UK.

40. Sigvald, R. 1987. Aphid migration and the importance of some aphid species as vectors of potato virus Yo (PVYo) in Sweden. Potato Res. 30:267-283.

41. Syller, J. 1991. The effects of temperature on the susceptibility of potato plants to infection and accumulation of potato leafroll virus. J. Phytopathol. 133:216-224.

42. Yalpani, Y., Silverman, P., Wilson, T. M. A., Kleier, D. A., and Raskin, T. 1991. Salicyllic acid is a systemic signal and an inducer of pathogenesis-related proteins in virus-infected tobacco. Plant Cell 3:809-818. 